\title{
The Level of Critical Land in West Lombok Using Geographic Information Systems
}

\author{
Barzian Ali Aktab ${ }^{1, *}$ Febrita Susanti ${ }^{1}$ Sri Apriani Puji Lestari ${ }^{1}$ \\ ${ }^{1}$ Universitas Muhammadiyah Mataram, Jl. K.H.Ahmad Dahlan No.1 , Nusa Tenggara Barat, Indonesia \\ ${ }^{*}$ Corresponding author. Email: barzianaliaktab@gmail.com
}

\begin{abstract}
Critical land is land that is caused by a decrease in the quality of the land as a medium for vegetation and a medium for water management, which causes the land to be degraded due to various types of land resource use that do not pay attention to the land. continuity. This study aims to analyze and map the level of criticality of land in the spatial pattern of West Lombok Regency. The analytical method used in determining the critical level of land in this study is the overlay method of spatial data based on parameters from the Regulation of the Director General of Watershed Management and Social Forestry Number: P.4 / V-SET / 2013 Regarding Technical Guidelines for Compiling Spatial Data for Critical Land, which consists of: indicators of land cover, slope, erosion hazard level, productivity, and management. The results of this study are the classification of the criticality level of land in protected forest areas, agricultural cultivation areas and areas outside forest areas which consist of lands with critical, moderately critical, potentially critical, and non-critical calcifications.
\end{abstract}

Keywords: Critical Land, Regulation, Geographic Information Systems.

\section{INTRODUCTION}

The increasing population growth in each region causes the need for land is also increasing[1]. Because land is resources that are very important in meeting the needs of human life, so a lot of land is used either as space needs living, cultivating crops, and as a supporting capacity for economic activity. In addition, the occurrence of environmental destruction such as deforestation or activities illegal logging, mining and quarrying activities $\mathrm{C}$, industrial activities and improper agricultural practices (agrochemical contamination) in land use causes a decrease in the quality of the land as media to grow plants and media to regulate the resulting water system land becomes degraded [2]. Where this condition certainly causes a land becomes critical [3] [4] [5] [6]. Critical land is not able to be effectively used for agricultural land, as a medium for regulating water management, as well as protection natural environment [7]. The main characteristics of critical land is bare, seems arid and even rocks appear on the ground and are generally located in areas with hilly land topography or steep slopes [8].

West Lombok Regency is a district that has the morphology of areas that are hilly / mountainous, plains, and coastal areas topography varies from flat, gentle and steep slopes. Diversity the morphology of the area, West Lombok Regency has saved natural resources are quite abundant, such as fertile land, areas forests, producing mining materials, and many other wealth resources other natural forces, both classified as biotic and abiotic utilized by the community. But in using it, the community West Lombok Regency still doesn't pay attention to sustainability land. One of the cases of environmental destruction that occurred in the Regency West Lombok, namely in the form of forest encroachment that occurs in the area Nuraksa Forest Park (Tahura) covering an area of 12 Ha. Forest encroachment This is done by burning the forest area for clearing new planting land for the community. Where is the result of forest encroachment it has been estimated that state losses amounting to IDR 45.07 billion [9].

Based on the regional characteristics which are the main characteristics of critical land and there are still environmental destructive practices in the form of encroachment forest which causes the land to be degraded thus causing land to become critical in West Lombok Regency. Based on data from the Environment and Forestry Service of Nusa Tenggara Province West, in 2018 West Lombok Regency has critical land which is in the status of a production forest area of $2,111 \mathrm{Ha}$, a 
forest area protected 2,209 $\mathrm{Ha}$, conservation forest area $434 \mathrm{Ha}$, and outside the forest area $61 \mathrm{Ha}$.

Based on the conditions described in the paragraph above, there are various factors that cause land to become critical in the West Lombok Regency area. So that critical land becomes one of the problems in West Lombok Regency. In addition, considering the need for land that continues to increase along with the population increase while the land area does not increase. Therefore, in this study the researcher attempted to determine the level of criticality of land in West Lombok Regency.

\section{METHOD}

The type of research used in this research is quantitative research with a descriptive approach.

\subsection{Research Sites}

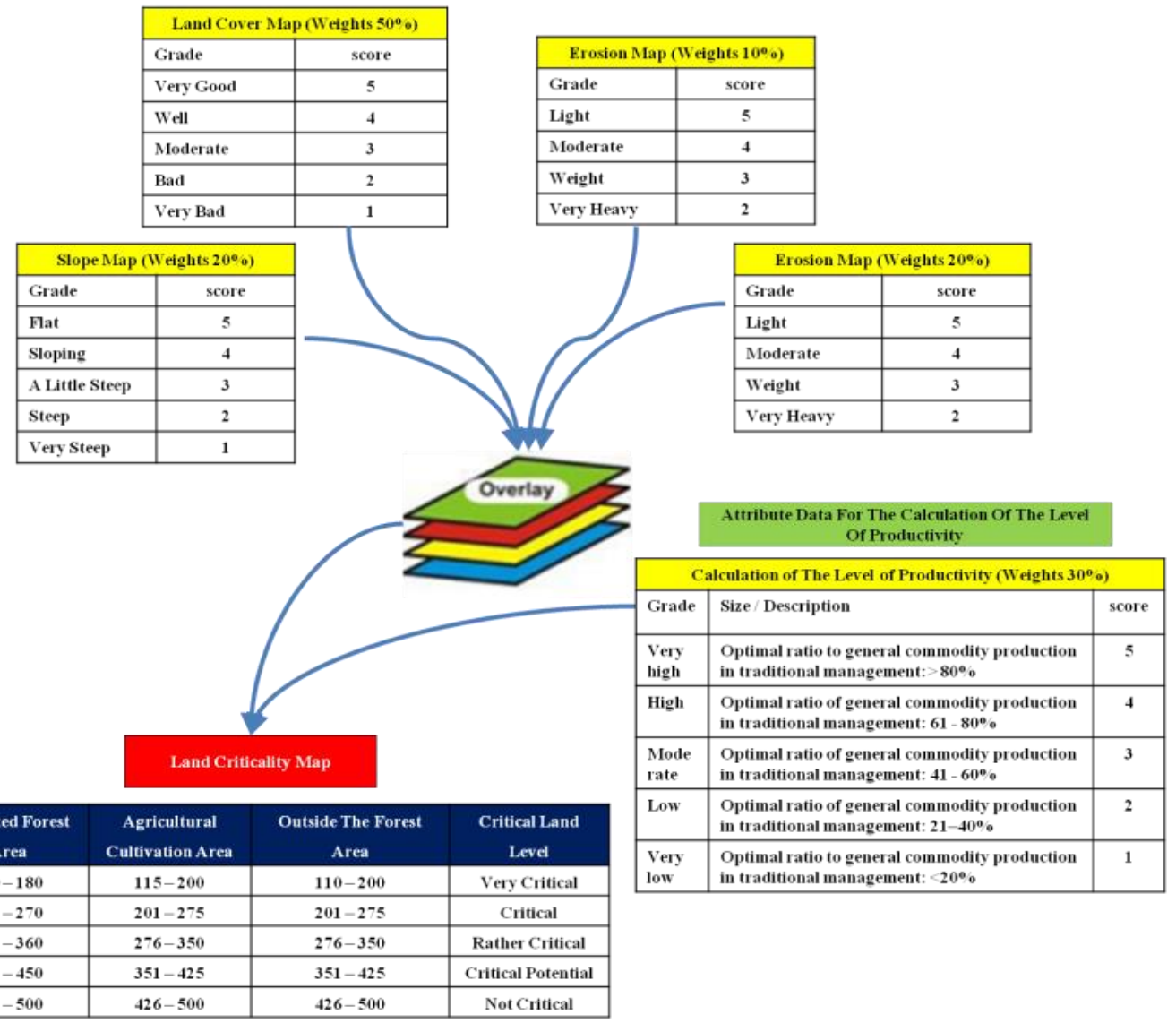

Figure 1 Data Analysis Method

\section{RESULT AND DISCUSSION}

\subsection{Land Cover}

The results of land cover analysis in West Lombok Regency show that land cover with very good class has the largest area, namely 49,092.43 Ha. And the land
The location of this research is West Lombok Regency which has the morphology of the hilly / mountainous, plains and coastal areas. Geographically, West Lombok Regency is located between 115 o 49.12 '04 "- 116o 20" 15.62 "East Longitude, and 8o 24" 33.82 "- 8o 55" 19 "South Latitude. West Lombok Regency itself has an area of $1,053.92 \mathrm{Km} 2$ which is divided into 10 sub-districts.

\subsection{Data analysis method}

The data analysis method used to determine the level of criticality of land in West Lombok Regency is by scoring techniques and spatial data overlay methods based on the parameters of the Regulation of the Director General of Watershed Management and Social Forestry Number: P. 4 / V-SET / 2013 Regarding Technical Guidelines for Spatial Data Compilation Critical Land in the following diagram (Figure 1). 
Table 1. Classification of Land Cover

\begin{tabular}{ccccc}
\hline Grade & Percentage of Header Cover $(\%)$ & Score & Score $\times$ Weigh $(50)$ & Area $($ Ha $)$ \\
\hline Very Good & $>80$ & 5 & 250 & $49.092,43$ \\
Well & $61-80$ & 4 & 200 & $13.097,51$ \\
Moderate & $41-60$ & 3 & 150 & $9.396,59$ \\
Bad & $21-40$ & 2 & 100 & $1.528,78$ \\
Very Bad & $<20$ & 1 & 50 & $32.276,69$ \\
\hline
\end{tabular}

\subsection{Slope}

The results of the slope classification in the West Lombok Regency area are dominated by a slope of 0 $8 \%$ with a flat slope class having an area of 30,064.48 Ha. The slope area of $8-15 \%$ with gentle slope class has an area of 17,535.48 Ha. Slope slope $15-25 \%$ with a rather steep slope class has an area of 18,183.47 Ha. Then the slope of 25 - $40 \%$ with steep slope class has an area of $26,191.48 \mathrm{Ha}$ and on slopes $>40 \%$ with very steep slope class has an area of 13,417.09 Ha. Where the slope that has slope class is getting steep, the more sensitive it will be to erosion so that the risk of critical land will also be even greater. The following is the weighting data on the slope parameters of West Lombok Regency (Table 2 and Figure 3).

Table 2. Calcification of Slope Slope of West Lombok Regency

\begin{tabular}{lllcc} 
Slope & Grade & Score & Score $\times$ Weight $(20)$ & Area $($ Ha $)$ \\
\hline $0-8 \%$ & Flat & 5 & 100 & $30.064,48$ \\
$8-15 \%$ & Sloping & 4 & 80 & $17.535,48$ \\
$15-25 \%$ & A Little Steep & 3 & 60 & $18.183,47$ \\
$25-40 \%$ & Steep & 2 & 40 & $26.191,48$ \\
$>40 \%$ & Very Steep & 1 & 20 & $13.417,09$ \\
\hline
\end{tabular}

\subsection{Erosion Hazard Level}

The results of the analysis of the status of the erosion hazard level in West Lombok Regency are dominated by the level of severe erosion hazard with an area of $37,915.51 \mathrm{Ha}(35.98 \%$ of the area of West Lombok Regency). Meanwhile, the risk of erosion in West
Lombok Regency, ranging from moderate to very severe, has an area of 66,960.94 Ha (63.54\% of the area of West Lombok Regency). This shows that the area of West Lombok Regency is at risk of extensive erosion hazards so that the risk of developing critical land will also be even greater. The following is a table of the status of erosion hazard levels in West Lombok Regency (Table 3 and Figure 4).

Table 3. Status of Erosion Hazard Level in West Lombok Regency

\begin{tabular}{ccccc}
\hline Erosion Rate (ton/ha/year) & Erosion Hazard Grade & Erosion Hazard Level & Score $\times$ Weight (20) & Area (Ha) \\
$<15$ & I & Very Light & 0 & 13343.42 \\
$15-60$ & II & Light & 5 & 25087.64 \\
$60-180$ & III & Moderate & 4 & 19714.32 \\
$180-480$ & IV & Weight & 3 & 37915.51 \\
$>480$ & V & Very heavy & 2 & 9331.11 \\
Total & & & 105392.00
\end{tabular}

\subsection{Calculation of the Level of Productivity}

The classification of agricultural productivity in West Lombok Regency is from very high class and low class. Where in general the amount of productivity of agricultural products in the West Lombok Regency is very high class (the ratio to the production of general commodities is optimal in traditional management:> $80 \%$ ). Except in the area of Batulayar Subdistrict, which has a low agricultural productivity classification (Ratio to optimal general commodity production in traditional management: $21-40 \%$ ). The following is a table of agricultural product productivity in West Lombok Regency in 2019 (Table 4). 
Table 4. Productivity of Agricultural Products in West Lombok Regency in 2019

\begin{tabular}{|c|c|c|c|c|c|c|c|}
\hline \multirow[b]{2}{*}{ Sub-district } & \multicolumn{7}{|c|}{ Productivity of Agricultural Products in West Lombok Regency in 2019} \\
\hline & $\begin{array}{l}\text { Harvested } \\
\text { Area }(\mathrm{Ha}) \\
\end{array}$ & $\begin{array}{l}\text { Production } \\
\text { (Ton) }\end{array}$ & $\begin{array}{l}\text { Productivity } \\
\text { (Ton/Ha) }\end{array}$ & $\begin{array}{l}\text { Amount of } \\
\text { Productivity }(\%)\end{array}$ & Grade & Score & $\begin{array}{l}\text { Score } \quad \times \\
\text { Weight (30) } \\
\end{array}$ \\
\hline Sekotong & 17232 & 99736.70 & 5.79 & 116.15 & Very High & 5 & 150 \\
\hline Lembar & 5969 & 32775.20 & 5.49 & 107.17 & Very High & 5 & 150 \\
\hline Gerung & 8569 & 52054.00 & 6.07 & 105.40 & Very High & 5 & 150 \\
\hline Labuapi & 3719 & 20426.73 & 5.49 & 102.47 & Very High & 5 & 150 \\
\hline Kediri & 3766 & 24251.10 & 6.44 & 116.62 & Very High & 5 & 150 \\
\hline Kuripan & 3526 & 20214.70 & 5.73 & 107.48 & Very High & 5 & 150 \\
\hline Narmada & 5911 & 33139.70 & 5.61 & 96.40 & Very High & 5 & 150 \\
\hline Lingsar & 3953 & 22855.50 & 5.78 & 102.56 & Very High & 5 & 150 \\
\hline Gunungsari & 2251 & 15364.15 & 6.83 & 120.78 & Very High & 5 & 150 \\
\hline Batulayar & 1918 & 2941.50 & 1.53 & 29.11 & Low & 2 & 60 \\
\hline
\end{tabular}

\subsection{Management}

The results of the management classification show that the management of protected forest areas in West
Lombok Regency is complete. Then the management value for determining critical land in the West Lombok Regency is given a value of 50 .

Table 5. Classification of management for determination critical land in West Lombok Regency

\begin{tabular}{|c|c|c|c|c|}
\hline Management of Protected Forest Area & $\begin{array}{c}\text { Completeness of } \\
\text { Management Aspects }\end{array}$ & Size/ Description & Score & $\begin{array}{c}\text { Score } \times \text { Weight } \\
(10)\end{array}$ \\
\hline Area boundaries exist & $\sqrt{ }$ & & & \\
\hline Supervision safeguards exist & $\sqrt{ }$ & Complete *) & 5 & 50 \\
\hline Extension carried out & $\sqrt{ }$ & & & \\
\hline
\end{tabular}

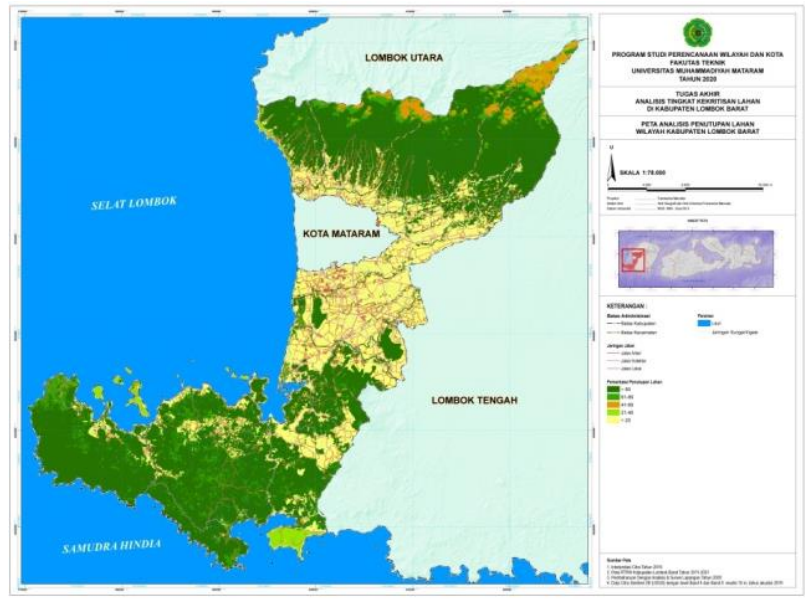

Figure 2 Land Cover

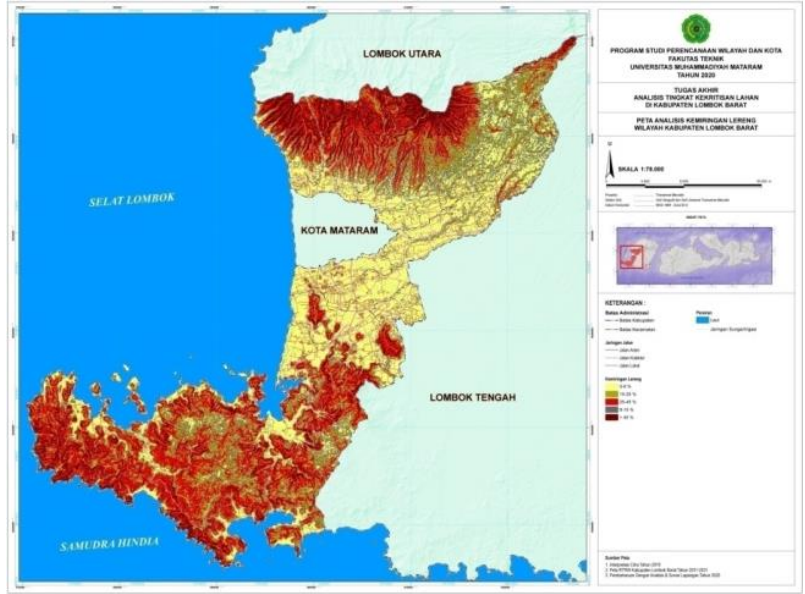

Figure 3 Slope 


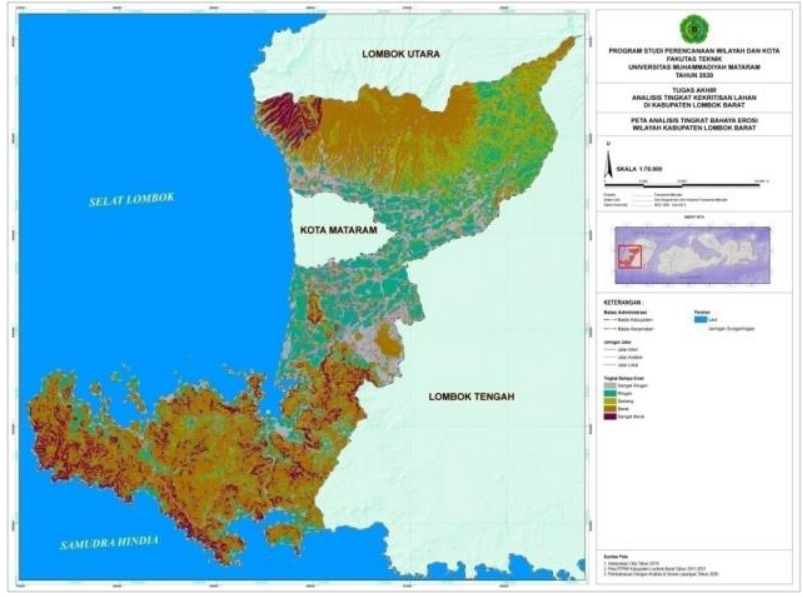

Figure 4 Erosion Hazard Level

\subsection{The Level of Criticality of Land in Protected Areas}

The results of the analysis of the criticality level of land in the protected forest area of West Lombok Regency are 3,714.38 Ha of land with a rather critical land classification. While the classification for potentially critical land has an area of 5,619.37 Ha. Where the level of land criticality that dominates in the protected forest area of West Lombok Regency is land with non-critical classification covering an area of 15,745.19 Ha (Figure 6).

\subsection{The Level of Soil Criticality in the Cultivation Area}

The results of the analysis of the criticality level of land in the agricultural cultivation area of West Lombok Regency, that the level of criticality of the land that

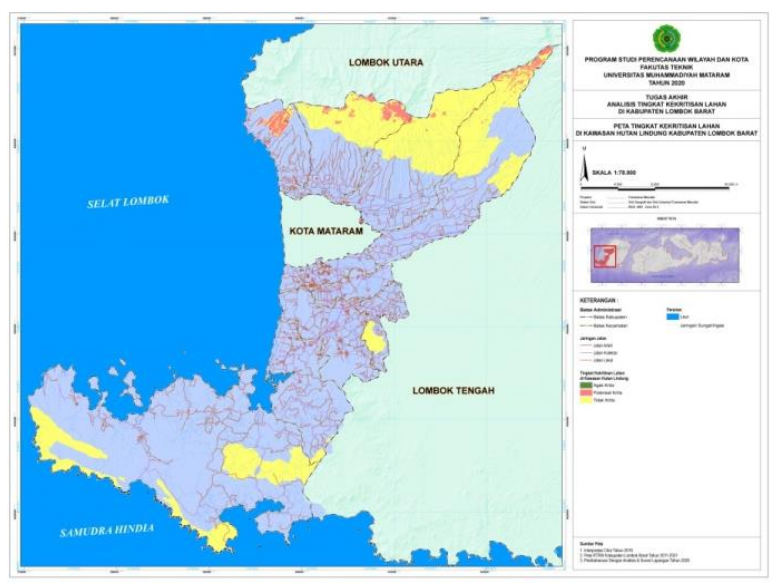

Figure 6 The level of criticality of land in protected areas

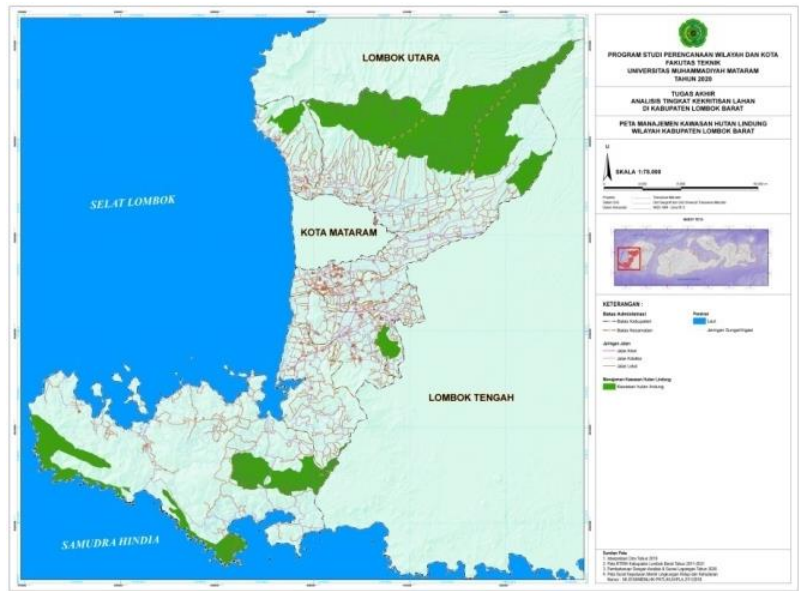

Figure 5 Management

dominates is land with non-critical classification covering an area of 24,689.35 Ha. The critical land classification has an area of $56.34 \mathrm{Ha}$ and for the land area with a slightly critical classification it has an area of $206.19 \mathrm{Ha}$. While the classification of critical potential lands has an area of $875.36 \mathrm{Ha}$ (Figure 7).

\subsection{The Critical Level of Land in Outer Areas Outside the Forest Zone}

The results of the analysis of the criticality level of land in areas outside the forest area of West Lombok Regency, there is a level of criticality with the critical land classification having an area of $587.37 \mathrm{Ha}$ and slightly critical land covering an area of 3,122.53 Ha. Meanwhile, the dominant land criticality level is land with non-critical classification with an area of 43,637.05 Ha. And the classification of critical potential land has an area of 7,138.87 Ha (Figure 8).

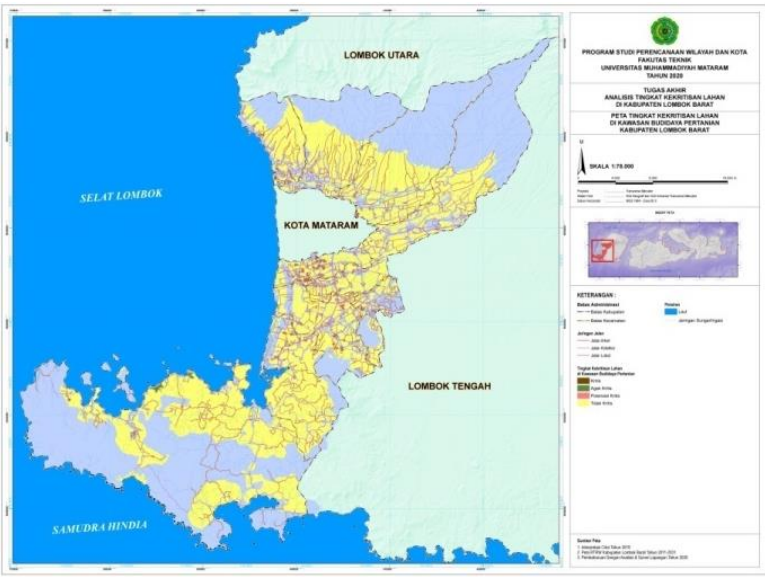

Figure 7 the level of soil criticality in cultivation area 


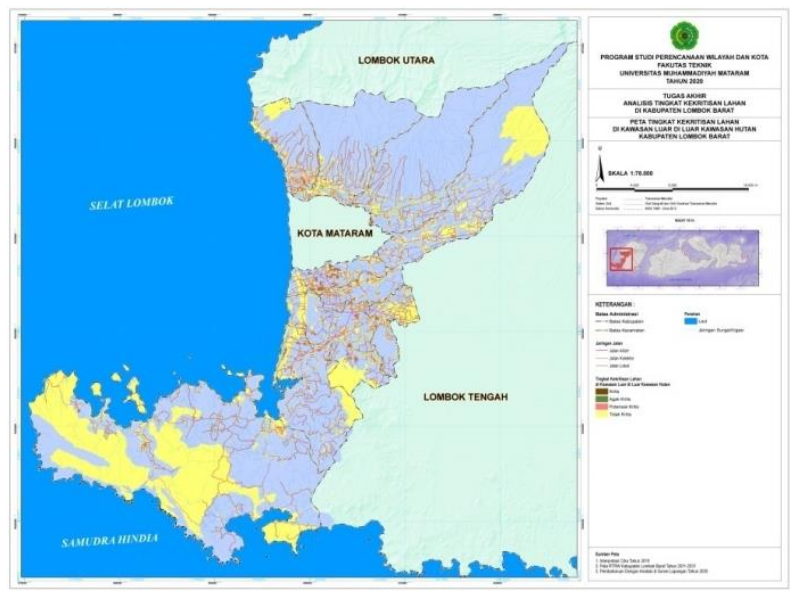

Figure 8. The critical level of land in outer areas outside the forest zone

\section{CONCLUSION}

The level of criticality of land that dominates in the protected forest area of West Lombok Regency is land with non-critical classification covering an area of 15,745.19 Ha. Then the level of criticality of land in the agricultural cultivation area of West Lombok Regency, that the level of criticality of the land that dominates is land with non-critical classification covering an area of $24,689.35 \mathrm{Ha}$. And for the level of land criticality that dominates in the outer areas outside the forest area of West Lombok Regency, namely land with non-critical classification with an area of 43,637.05 Ha.

\section{REFERENCES}

[1] R. F. Putri, M. Naufal, M. Nandini, D. S. Dwiputra, S. Wibirama and J. T. S Sumantyo, "The Impact of Population Pressure on Agricultural Land," in IOP Conf. Series: Earth and Environmental Science, 2019.

[2] A. Kurniawan, F. Susanti and S. R. Yunianti, "Strategy to develop tourism objects at Ijobalit, a former," in IOP Conf. Series: Earth and Environmental Science, Mataram, 2020.

[3] M. Mortimore, "Population Growth and Land Degradation," GeoJurnal, vol. XXXI, no. 1, pp. 1521, 1993.

[4] R. E. Putri, M. Naufal, D. S. Dwiputra, S. Wibirama and J. T. S. Sumantyo, "The impact of Population Pressure on Agricultural Land towards Food
Sufficiency (Case in West Kalimantan Province, Indonesia)," in International Conference on Enviromental Resources management in Global Region, 2019.

[5] R. E. Bilsborrow, A. F. Barbieri and W. Pan, "Changes in Population and Land use over tme in the Ecuadorian Amazon," Acta Amazonica, vol. XXXIV, no. 4, pp. 635-647, 2004.

[6] S. Y. J. Prasetyo, B. H. S, K. D. Hartomo, M. Paseleng and B. Nuswantoro, "Geographic Information System of Critical Level of Land Degradation (Critical Land) Based on Agroecological Zone (AEZ) in Agricultural Areas with Recombination Method of Fuzzy Logic and Scoring," IJCSI International Journal of Computer Science Issues, vol. X, no. 6, pp. 217-221, 2013.

[7] M. Rosyada, Y. Prasetyo and H. , "Penentuan Tingkat Lahan Kritis Menggunakan Metode Pembobotan dan Algoritma NDVI," geodesi UNDIP, vol. 4, no. 1, pp. 85-94, 2015.

[8] N. Bashit, "ANALISIS LAHAN KRITIS BERDASARKAN KERAPATAN TAJUK POHON MENGGUNAKAN CITRA SENTINEL 2," Jurnal Geodesi dan Geomatika, vol. 2, no. 01, pp. 71-79, 2019.

[9] B. D. Pratama, Polhut Mengungkap Kasus Perambahan 12 Hektar Lahan Tahura Nuraksa, Mataram: ANTARA News Mataram, 2019. 